\title{
Summary of OEM Idling Recommendations from Vehicle Owner's Manuals
}

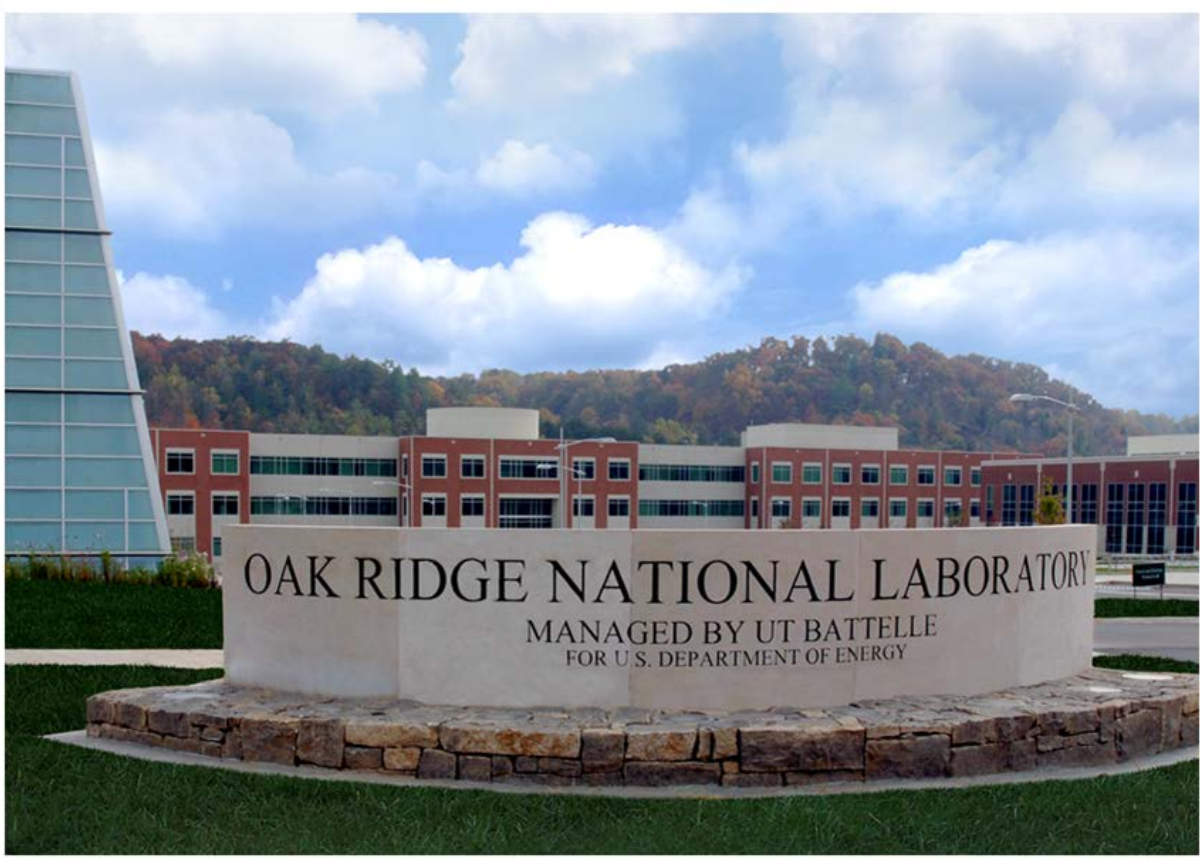

Kristy Keel-Blackmon

Scott Curran

Melissa Lapsa

June 2016 


\title{
DOCUMENT AVAILABILITY
}

Reports produced after January 1, 1996, are generally available free via US Department of Energy (DOE) SciTech Connect.

\section{Website http://www.osti.gov/scitech/}

Reports produced before January 1, 1996, may be purchased by members of the public from the following source:

\author{
National Technical Information Service \\ 5285 Port Royal Road \\ Springfield, VA 22161 \\ Telephone 703-605-6000 (1-800-553-6847) \\ TDD 703-487-4639 \\ Fax 703-605-6900 \\ E-mail info@ntis.gov \\ Website http://www.ntis.gov/help/ordermethods.aspx
}

Reports are available to DOE employees, DOE contractors, Energy Technology Data Exchange representatives, and International Nuclear Information System representatives from the following source:

Office of Scientific and Technical Information

PO Box 62

Oak Ridge, TN 37831

Telephone 865-576-8401

Fax 865-576-5728

E-mail reports@osti.gov

Website http://www.osti.gov/contact.html

This report was prepared as an account of work sponsored by an agency of the United States Government. Neither the United States Government nor any agency thereof, nor any of their employees, makes any warranty, express or implied, or assumes any legal liability or responsibility for the accuracy, completeness, or usefulness of any information, apparatus, product, or process disclosed, or represents that its use would not infringe privately owned rights. Reference herein to any specific commercial product, process, or service by trade name, trademark, manufacturer, or otherwise, does not necessarily constitute or imply its endorsement, recommendation, or favoring by the United States Government or any agency thereof. The views and opinions of authors expressed herein do not necessarily state or reflect those of the United States Government or any agency thereof. 
Energy and Transportation Sciences Division

\title{
Summary of OEM Idling Recommendations from Vehicle Owner's Manuals
}

\author{
Kristy Keel-Blackmon \\ East Tennessee Clean Fuels Coalition \\ Scott Curran, Melissa Lapsa \\ Oak Ridge National Laboratory
}

January 2016

Prepared by

OAK RIDGE NATIONAL LABORATORY

Oak Ridge, TN 37831-6283

managed by

UT-BATTELLE, LLC

for the

US DEPARTMENT OF ENERGY

under contract DE-AC05-00OR22725 



\section{CONTENTS}

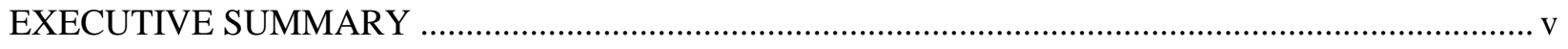

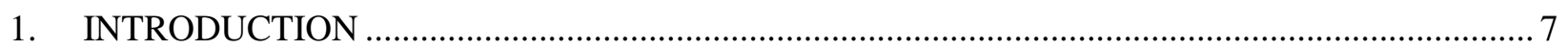

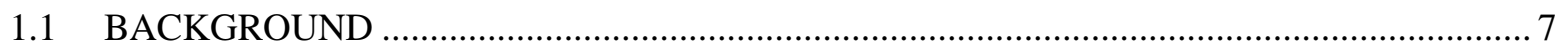

1.2 PURPOSE

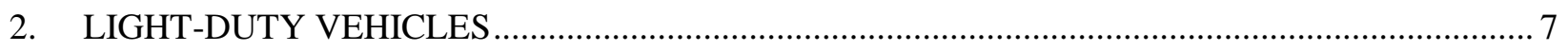

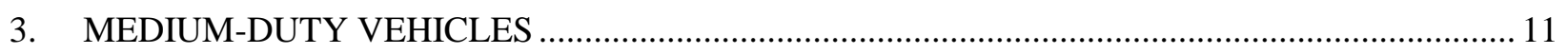

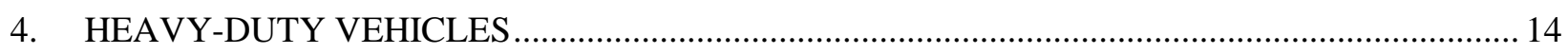

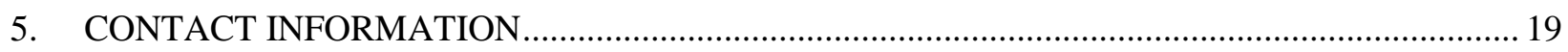

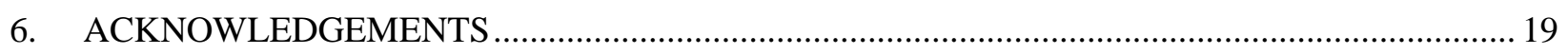





\section{EXECUTIVE SUMMARY}

The project upon which this report is based was conceived in 2012 during discussions between the East Tennessee Clean Fuels Coalition (ETCleanFuels) and Oak Ridge National Laboratory (ORNL) who both noted that a detailed summary of idling recommendations for a wide variety of engines and vehicles were not available in the literature. The two organizations agreed that ETCleanFuels would develop a first-ofits-kind collection of idling recommendations from the owner's manuals of modern production vehicles.

Vehicle engine idling, a subject that has long been debated, is largely shrouded in misinformation. The justifications for idling seem to be many: driver comfort, waiting in lines, and talking on cell phones to name a few. Assuredly, a great number of people idle because of the myths and misinformation surrounding this issue. This report addresses these myths by turning to statements taken directly from the automobile and engine manufacturers themselves.

None of the manufacturers mentioned in this report recommend extended idle time. In fact, the vast majority recommend that drivers avoid excessive idle time and idle only if necessary. Light-duty vehicles are ready to be driven at start up, and neither mediumnor heavy-duty vehicles need long warm up periods. According to many original equipment manufacturers (OEMs), idling can actually be damaging to an engine and vehicle components. This is because idling can produce sulfuric acid, which can eat away at the engine and other components. Additionally, idling results in lower incylinder temperatures combustion, which can produce additional soot, creates buildup

\section{Common Myths About Idling}

- Idling is more efficient and uses less fuel than turning the engine off and on again.

- Turning the engine off and on is hard on the starter.

- Idling is the best way to warm up the engine, especially in cold weather.

- Idling does not cause damage to a vehicle's engine.

in the engine, and causes unnecessary engine wear. Based on the potential for engine damage, drivers should avoid idling whenever possible

In addition to increased engine wear and tear, idling should be avoided for other important reasons. Vehicles get 0 MPG and fuel is unnecessarily wasted while idling. This wasted fuel can be costly over the course of a year, especially for fleets. The amount of fuel wasted will vary from vehicle to vehicle and depends on a number of conditions; however, a good rule of thumb to remember is that the larger the engine, the more fuel will be wasted while idling. ${ }^{1}$ Many OEMs also state that engine oil can be affected by extended idling because the oil becomes contaminated, resulting in a decrease in oil life and thus the need for more frequent oil changes-another expense.

The harmful emissions that idling creates should also be considered. These emissions include nitrogen oxides, carbon monoxide, carbon dioxide, and particulate matter. ${ }^{1}$ Some of these pollutants pose health threats on their own, and some will come into contact with heat and sunlight to form ground level ozone, a potent pollutant that can worsen asthma and other respiratory problems and cause reduced lung

\footnotetext{
${ }^{1}$ Transportation Technology R\&D Center, http://www.transportation.anl.gov/engines/idling_research.html, Argonne National Laboratory, Argonne, Illinois, April 2011.
} 
function. Ground level ozone is especially harmful to children, the elderly, people who work or exercise outside, and people with existing lung problems. ${ }^{2}$

As stated previously, idling is occasionally necessary, as is the case for some delivery trucks, instances of extreme weather, or waiting in a slow-moving line. However, most idling is unnecessary and can be eliminated through conscious effort. Some manufacturers do recommend a very short warmup or cooldown period, but only if a vehicle has been under high-power operation. Generally speaking, more than 5 minutes of idling is excessive and should be avoided.

${ }^{2}$ State of the Air 2010, http://www.lung.org/assets/documents/publications/state-of-the-air/state-of-the-air-report-2010.pdf, American Lung Association, Washington, DC, 2010. 


\section{INTRODUCTION}

This report and the project on which it is based were conceived in 2012 during discussions between the East Tennessee Clean Fuels Coalition (ET Clean Fuels) and Oak Ridge National Laboratory (ORNL) who both noted that a detailed summary of idling recommendations for a wide variety of engines and vehicles were not available in the literature. The two organizations agreed that ET Clean Fuels would develop a first-of-its-kind collection of idling recommendations from manufactures.

\subsection{BACKGROUND}

While idling recommendations for some light-duty (LD), medium-duty (MD), and heavy-duty (HD) vehicles can be found in various sources, that information may be misstated or inaccurate depending on the source. Drivers of all types of vehicles may behave according to the many common misconceptions about idling. Often drivers believe or assume that leaving an engine running is more beneficial than turning it off when, in fact, most manufacturers recommend idling only for very limited periods or not at all.

\subsection{PURPOSE}

The purpose of this work is to amass the best idling recommendations for LD, MD, and HD vehicles. Depending on the company or manufacturer, the amount of information provided on idling varies or may be contained in different formats. While not an all-inclusive compendium of idling information, this summary does aggregate the best current and older recommendations from original equipment manufacturers (OEMs) and other sources available at the time of the compilation to present the information in one location.

The following sections cover LD, MD, and HD vehicle idling recommendations. The information in the tables in each section is presented alphabetically by OEM.

For this work, the following gross vehicle weight rating mass categories were used.

- $\quad<10,000$ pounds-light duty

- $10,000-26,000$ pounds - medium duty

- $>26,001$ - heavy duty

\section{LIGHT-DUTY VEHICLES}

Summary of idling recommendations for LD vehicles

- Avoid idling for long periods of time.

- Idling beyond 30 seconds is excessive and should be avoided.

- Extended idling wastes fuel and causes reduction in fuel economy.

- Excessive idling can affect the life of engine oil.

- Idling is not the appropriate way to warm the engine at start-up. 


\begin{tabular}{|c|c|c|}
\hline OEM & Recommendation & Reference \\
\hline \multirow[t]{4}{*}{ BMW } & $\begin{array}{l}\text { Drive away without delay. Do not wait for the engine to warm } \\
\text { up while the vehicle remains stationary. Switch off the engine } \\
\text { during longer stops, e.g., at traffic lights, at railroad crossings, } \\
\text { or in traffic congestion. }\end{array}$ & $\begin{array}{l}20136 \text { Series, X3 Manuals } \\
2006 \text { Z4 Coupe Manual }\end{array}$ \\
\hline & $\begin{array}{l}\text { Do not race the engine while warming it up. Drive at moderate } \\
\text { speed for a short distance first, especially in cold weather. }\end{array}$ & 2009 328i Manual \\
\hline & $\begin{array}{l}\text { Do not allow the engine to warm up by leaving it running } \\
\text { while the vehicle remains stationary. Instead, begin to drive at } \\
\text { a moderate engine speed. }\end{array}$ & 2008 535i Manual \\
\hline & $\begin{array}{l}\text { Driving off immediately: Do not allow the engine to warm up } \\
\text { by leaving it running while the vehicle remains stationary. } \\
\text { Instead, begin to drive at a moderate engine speed. This is the } \\
\text { fastest way for the cold engine to reach its operating } \\
\text { temperature. }\end{array}$ & $\begin{array}{l}2010 \text { 328i xDrive Sedan Manual } \\
2008 \text { 650i Coupe Manual } \\
2008 \text { 128i Coupe Manual }\end{array}$ \\
\hline \multirow[t]{2}{*}{ Cadillac } & Avoid idling the engine for long periods of time. & $\begin{array}{l}2013 \text { ATS, XTS Manual } \\
2010 \text { Escalade/Escalade ESV } \\
\text { Manual } \\
2009 \text { CTS/CTS-V Manual } \\
2009 \text { Escalade/Escalade ESV } \\
\text { Manual }\end{array}$ \\
\hline & It is better not to park with the engine running. & $\begin{array}{l}2011 \text { Escalade/Escalade ESV } \\
\text { Manual } \\
2010 \text { Escalade/Escalade ESV } \\
\text { Manual } \\
\text { 2009 STS/STS-V Manual } \\
\text { 2009 Escalade/Escalade ESV } \\
\text { Manual } \\
\text { 2009 SRX Manual } \\
\end{array}$ \\
\hline \multirow[t]{4}{*}{ Chevrolet } & $\begin{array}{l}\text { It is better not to park with the engine running. } \\
\text { Do not race the engine immediately after starting it. Operate } \\
\text { the engine and transmission gently to allow the oil to warm up } \\
\text { and lubricate all moving parts. }\end{array}$ & $\begin{array}{l}2012 \text { Chevrolet Express Manual } \\
2008 \text { Equinox, HHR Manuals }\end{array}$ \\
\hline & $\begin{array}{l}\text { Avoid idling the engine for long periods of time. } \\
\text { It is better not to park with the engine running. } \\
\text { Do not race the engine immediately after starting it. Operate } \\
\text { the engine and transmission gently to allow the oil to warm up } \\
\text { and lubricate all moving parts. }\end{array}$ & $\begin{array}{l}2013 \text { Malibu Manual } \\
2012 \text { Chevy Corvette, Impala } \\
\text { Manuals } \\
2011 \text { HHR, Aveo Manuals } \\
2010 \text { HHR, Aveo, Malibu, } \\
\text { Cobalt Coupe Manuals } \\
2009 \text { Silverado Manual } \\
\end{array}$ \\
\hline & $\begin{array}{l}\text { Do not warm up the car. Even on the coldest mornings, the } \\
\text { vehicle is ready to go in just } 30 \text { seconds. In fact, vehicles reach } \\
\text { optimum operating temperatures faster when driven instead of } \\
\text { idling. }\end{array}$ & $\begin{array}{l}\text { http://www.youtube.com/watch } \\
\text { ?v=ZfB3HuNbn2M }\end{array}$ \\
\hline & $\begin{array}{l}\text { Avoid idling: A car gets } 0 \text { mpg when the engine is idling: } \\
\text { While it does take a small amount of fuel to restart a vehicle, } \\
15 \text { minutes in the drive-through can burn through a quarter of } \\
\text { a gallon of fuel. }\end{array}$ & $\begin{array}{l}\frac{\text { http://media.gm.com/product/pu }}{\text { blic/us/en/FuelEfficiency/tips.ht }} \\
\underline{\underline{\mathrm{ml}}}\end{array}$ \\
\hline Ford & $\begin{array}{l}\text { Don't idle for more than } 30 \text { seconds. Today's engines don’t } \\
\text { need to be warmed up. Prolonged idling creates excess } \\
\text { emissions and wastes fuel. Start the car and immediately drive } \\
\text { away. Older model, non-fuel-injected vehicles needed warmup } \\
\text { time. We recommend you check with the service department } \\
\text { of your local Ford dealership regarding specific engines. }\end{array}$ & $\begin{array}{l}\text { http://corporate.ford.com/news- } \\
\text { center/press-releases- } \\
\underline{\text { detail/ecodriving-458p }}\end{array}$ \\
\hline
\end{tabular}




\begin{tabular}{|c|c|c|}
\hline \multirow[t]{2}{*}{ Ford cont. } & $\begin{array}{l}\text { No idling-Today's engines don't need a warmup. Start the } \\
\text { car immediately and gently drive away. Don’t leave your car } \\
\text { idling. Prolonged idling increases emissions and wastes fuel. } \\
\text { Turn the engine off in non-traffic situations, such as at bank } \\
\text { and fast food drive-up windows when idling more than } 30 \\
\text { seconds. }\end{array}$ & $\begin{array}{l}\text { http://media.ford.com/article_di } \\
\text { splay.cfm?article_id=28946, } \\
\text { http://corporate.ford.com/news- } \\
\text { center/press-releases- } \\
\text { detail/ecodriving-458p }\end{array}$ \\
\hline & $\begin{array}{l}\text { Turn your engine off when sitting in a parking lot, in line at } \\
\text { the drive-thru, or waiting at the car wash. }\end{array}$ & $\begin{array}{l}\text { http://www.youtube.com/watch } \\
\text { ?v=2b7nMW-LIdI }\end{array}$ \\
\hline GMC & Avoid idling the engine for long periods of time. & $\begin{array}{l}\text { http://www.gmc.com/fuel- } \\
\text { efficiency.html }\end{array}$ \\
\hline Honda & $\begin{array}{l}\text { Avoid excess idling. Idling results in } 0 \mathrm{mpg}(0 \mathrm{~km} / \mathrm{L}) \text {. Fuel } \\
\text { economy factors: excessive idling. }\end{array}$ & $\begin{array}{l}2009 \text { Ridgeline, Fit Manuals } \\
2010 \text { CRV Manual }\end{array}$ \\
\hline \multirow[t]{2}{*}{ Hyundai } & $\begin{array}{l}\text { "While during the break in period avoid idling for longer than } \\
3 \text { minutes, after the break in period of } 600 \text { miles avoid idling } \\
\text { at high engine speeds for longer than } 5 \text { minutes." }\end{array}$ & $\begin{array}{l}\text { Correspondence with Hyundai } \\
\text { representative }\end{array}$ \\
\hline & $\begin{array}{l}\text { Don't let the engine idle longer than necessary. If you are } \\
\text { waiting (and not in traffic), turn off your engine and restart } \\
\text { only when you're ready to go. Remember, your vehicle does } \\
\text { not require extended warm-up. After the engine has started, } \\
\text { allow the engine to run for } 10 \text { to } 20 \text { seconds before placing the } \\
\text { vehicle in gear. In very cold weather, however, give your } \\
\text { engine a slightly longer warm-up period. }\end{array}$ & 2010 Elantra Manual \\
\hline Infiniti & $\begin{array}{l}\text { Allow the engine to idle for at least } 30 \text { seconds after starting. } \\
\text { Do not race the engine while warming it up. Drive at moderate } \\
\text { speed for a short distance first, especially in cold weather. In } \\
\text { cold weather, keep the engine running for a minimum of } 2-3 \\
\text { minutes before shutting it off. Starting and stopping the engine } \\
\text { over a short period of time may make the vehicle more } \\
\text { difficult to start. }\end{array}$ & $\begin{array}{l}2012 \text { FX Manual } \\
2008 \text { G Manual } \\
\text { JX Owners Manual } \\
\text { QX Owners Manual }\end{array}$ \\
\hline \multirow[t]{3}{*}{ Lincoln } & $\begin{array}{l}\text { After idling for a few seconds, release the parking brake, apply } \\
\text { the brake, shift into gear, and drive. } \\
\text { Idling for long periods of time (longer than } 1 \text { minute) may } \\
\text { waste fuel. }\end{array}$ & $\begin{array}{l}2010 \text { Navigator Manual } \\
2007 \text { Town Car Manual } \\
2000 \text { LS Manual }\end{array}$ \\
\hline & Extended engine idling decreases fuel economy. & $\begin{array}{l}1996 \text { Lincoln Continental } \\
\text { Manual }\end{array}$ \\
\hline & $\begin{array}{l}\text { There are also some things you may not want to do because } \\
\text { they may reduce your fuel economy, e.g., idling for periods } \\
\text { longer than } 1 \text { minute. }\end{array}$ & 2013 MKS Manual \\
\hline \multirow[t]{2}{*}{ Mazda } & $\begin{array}{l}\text { After idling for a few seconds, release the parking brake, apply } \\
\text { the brake, shift into gear, and drive. } \\
\text { Idling for long periods of time, e.g., more than } 1 \text { minute, may } \\
\text { waste fuel. }\end{array}$ & 2011 Tribute Manual \\
\hline & $\begin{array}{l}\text { After starting the engine, let it idle for about } 10 \text { seconds. } \\
\text { Do not operate the engine at high idle for more than } 5 \text { minutes. }\end{array}$ & 2010 Mazda 6 Manual \\
\hline \multirow[t]{2}{*}{$\begin{array}{l}\text { Mercedes- } \\
\text { Benz }\end{array}$} & Do not warm up the engine with the vehicle stationary. & $\begin{array}{l}\text { 2011 Maintenance Manual: } \\
\text { http://www.mbusa.com/vcm/M } \\
\text { B/DigitalAssets/pdfmb/mainten } \\
\text { ancebooklets/2011_Maintenanc } \\
\text { e_Manual.pdf }\end{array}$ \\
\hline & $\begin{array}{l}\text { Idling your Mercedes-Benz can use a quarter to a half gallon } \\
\text { of fuel per hour, depending on engine size and air conditioner }\end{array}$ & $\begin{array}{l}\text { http://www.mercedes- } \\
\text { jacksonville.com/2011/10/five- }\end{array}$ \\
\hline
\end{tabular}




\begin{tabular}{|c|c|c|}
\hline & use. Turn off the engine when your vehicle is parked. & $\begin{array}{l}\text { tips-to-maximize-mercedes- } \\
\text { benz-fuel-efficiency/ }\end{array}$ \\
\hline Nissan & $\begin{array}{l}\text { Avoid unnecessary engine idling. } \\
\text { Allow the engine to idle for at least } 30 \text { seconds after starting. } \\
\text { Do not race the engine while warming it up. Drive at moderate } \\
\text { speed for a short distance first, especially in cold weather. } \\
\text { In cold weather, keep the engine running for a minimum of 2- } \\
3 \text { minutes before shutting it off. Starting and stopping the } \\
\text { engine over a short period of time may make the vehicle more } \\
\text { difficult to start. } \\
\text { Extensive idling may require more oil and filter changes. }\end{array}$ & $\begin{array}{l}2012 \text { Altima Manual } \\
2011 \text { Quest Manual } \\
2010 \text { Maxima Manual } \\
2009 \text { Z Roadster Manual } \\
2008 \text { XTerra Manual }\end{array}$ \\
\hline \multirow[t]{3}{*}{ Toyota } & $\begin{array}{l}\text { The longer the warming-up time is, the more fuel will be lost. } \\
\text { Set off just after starting the engine. If you start the engine } \\
\text { when it's very cold or if you're starting an engine that has not } \\
\text { been run for several days or more, wait for some dozens of } \\
\text { seconds after starting the engine until oil is distributed } \\
\text { throughout the engine and then set off. }\end{array}$ & $\begin{array}{l}\text { http://www.toyota- } \\
\text { global.com/sustainability/enviro } \\
\text { nmental_responsibility/global } \\
\text { warming_prevention_initiatives/ } \\
\text { eco_driving/eco_driving_at_its_ } \\
\text { best.html\#start }\end{array}$ \\
\hline & $\begin{array}{l}\text { Stop the engine instead of idling, if possible. Stop the engine, } \\
\text { even for a short time, such as when stopping by a convenience } \\
\text { store, when loading or unloading, or when waiting for an } \\
\text { empty space in a parking lot. If the engine is running, gasoline } \\
\text { will be consumed even if the car is stopped. }\end{array}$ & $\begin{array}{l}\text { http://www.toyota- } \\
\text { global.com/sustainability/enviro } \\
\text { nmental_responsibility/global } \\
\text { warming_prevention_initiatives/ } \\
\text { eco_driving/eco_driving_at_its } \\
\text { best.html\#start }\end{array}$ \\
\hline & $\begin{array}{l}\text { Avoid lengthy warmup idling. Once the engine is running } \\
\text { smoothly, begin driving - but gently. Remember, however, } \\
\text { that on cold winter days this may take a little longer. } \\
\text { Avoid long engine idling. If you have a long wait and you are } \\
\text { not in traffic, it is better to turn off the engine and start again } \\
\text { later. }\end{array}$ & $\begin{array}{l}2008 \text { Matrix Manual } \\
2007 \text { Camry Manual } \\
2005 \text { Avalon Manual } \\
2001 \text { Highlander Manual } \\
2000 \text { Rav4 Manual } \\
1999 \text { Tercel Manual } \\
1998 \text { 4Runner Manual } \\
\end{array}$ \\
\hline \multirow[t]{2}{*}{ Volkswagen } & $\begin{array}{l}\text { Do not let your vehicle warm up while standing; instead, start } \\
\text { driving right away after making sure that you have good } \\
\text { visibility through all windows. This will help the engine reach } \\
\text { operating temperature faster and keep emissions down. }\end{array}$ & $\begin{array}{l}\text { Current Volkswagen Owners } \\
\text { Manuals }\end{array}$ \\
\hline & Avoid idling. You get 0 MPG when you idle. & $\begin{array}{l}\text { http://www.vw.com/en/owners/ } \\
\text { parts-and-accessories/care/fuel- } \\
\text { efficiency.html }\end{array}$ \\
\hline Volvo & $\begin{array}{l}\text { Don't let your car run at idling speed unless necessary (it's } \\
\text { worth your while to switch off the engine if you're going to be } \\
\text { at a standstill for more than } 20 \text { or } 30 \text { seconds). }\end{array}$ & $\begin{array}{l}\text { http://www.swedespeed.com/art } \\
\text { man2/publish/Volvo_News/Vol } \\
\text { vo_Cars_Driving_Academy_- } \\
\text { Interest_in_Eco- } \\
\text { Drivi_1073.html }\end{array}$ \\
\hline
\end{tabular}




\section{MEDIUM-DUTY VEHICLES}

Summary of idling recommendations for MD vehicles

- Avoid excessive idling.

- Idling beyond 5-15 minutes is excessive and should be avoided.

- Extended idling wastes fuel and causes reduction in fuel economy.

- Excessive idling can create engine wear and carbon soot buildup in the engine and components.

- Idle time at cooldown is only required if vehicle is operated under extended, high power conditions.

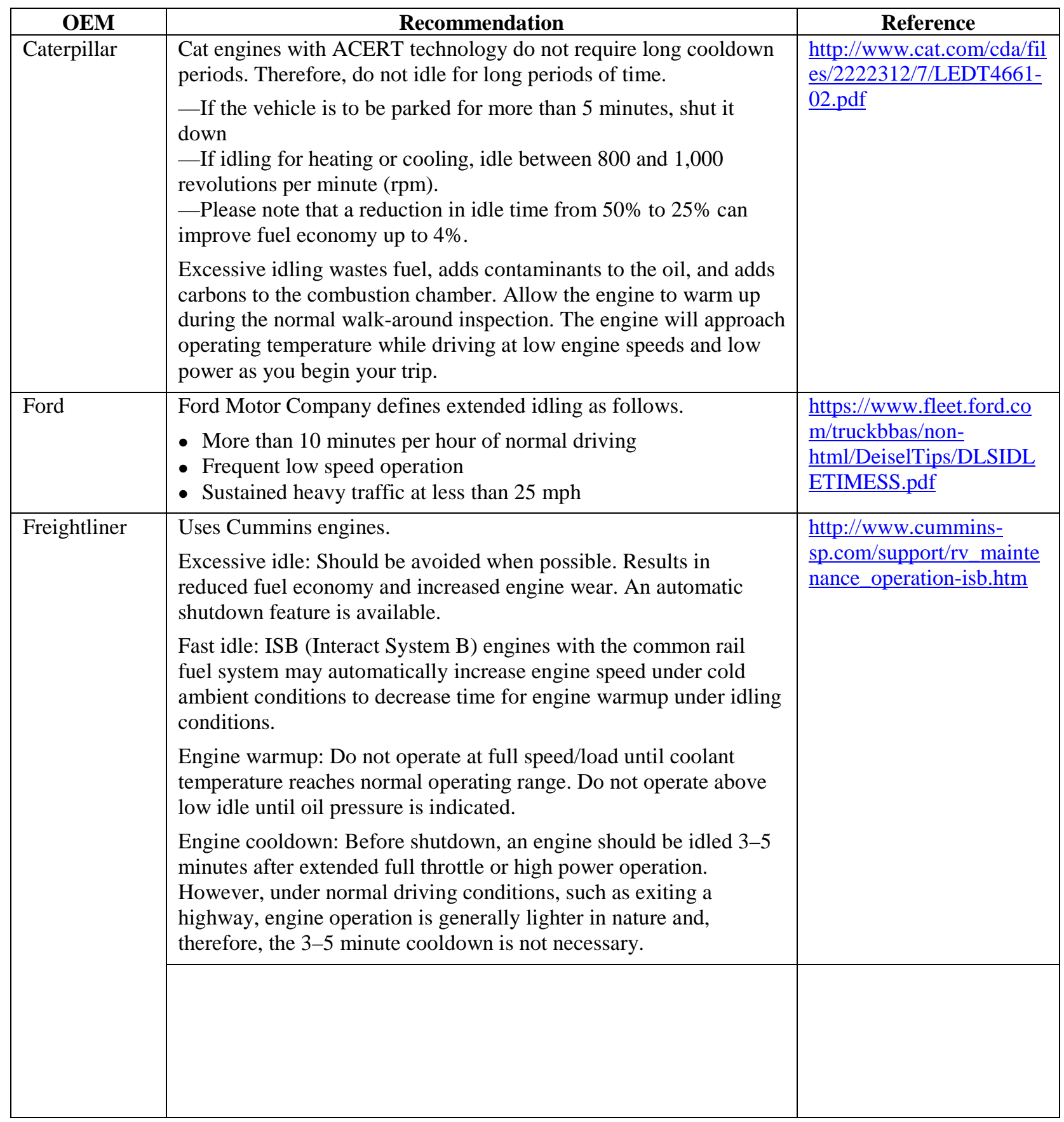




\begin{tabular}{|c|c|c|}
\hline $\begin{array}{l}\text { Freightliner } \\
\text { cont. }\end{array}$ & $\begin{array}{l}\text { Uses Cummins engines. } \\
\text { Internal combustion engines must not operate at low idle speed for } \\
\text { extended periods of time. This operating condition may lead to poor } \\
\text { engine performance. The idle shutdown feature, available on most } \\
\text { Cummins engines, can be programmed to shut the engine down } \\
\text { after a period of low idle speed operation with no driver activity. A } \\
\text { flashing warning lamp will inform the driver of an impending } \\
\text { shutdown. If an engine must idle for an extended period of time, it } \\
\text { should be done at fast idle (1,000 rpm or greater). The Power Take } \\
\text { Off (PTO) feature, available on most Cummins engines, can be } \\
\text { programmed to adjust engine speed with the use of OEM switches } \\
\text { to preprogrammed setpoints. }\end{array}$ & $\begin{array}{l}\text { Cummins Operation and } \\
\text { Maintenance Manuals } \\
\text { ISL, ISC, ISB, Section } \\
\text { 101-015 “Operating the } \\
\text { Engine” }\end{array}$ \\
\hline International & $\begin{array}{l}\text { Uses MaxxForce engines. } \\
\text { Low idle speed for the MaxxForce DT, 9, and } 10 \text { diesel engines is } \\
700 \text { rpm (nonadjustable). If the engine coolant temperature is below } \\
70^{\circ} \mathrm{C}\left(158^{\circ} \mathrm{F}\right) \text {, the electronic control module will adjust the low idle } \\
\text { speed from } 700 \text { rpm to a maximum of } 875 \text { rpm. High idle speed is a } \\
\text { nonadjustable factory setting. The high idle setting depends on the } \\
\text { application of the vehicle and has the following ranges: MaxxForce } \\
\text { DT: } 2,600 \text { rpm through } 2,770 \text { rpm; MaxxForce } 9 \text { and } 10: 2,325 \text { rpm } \\
\text { through 2,425 rpm. To prevent engine damage, do not extend low } \\
\text { idle periods. Idling periods over } 15 \text { minutes should be avoided. } \\
\text { Diesel engine efficiency is improved when the cylinder temperature } \\
\text { remains high. Low temperature in cylinders may cause the } \\
\text { following: (1) unburned fuel to seep from exhaust manifold gaskets } \\
\text { and vehicle exhaust system connections (this seepage has the dark- } \\
\text { colored appearance of lubricating oil); (2) incomplete combustion, } \\
\text { resulting in unburned fuel, which washes lubricating oil from } \\
\text { cylinder sleeves; (3) unburned fuel to be carried into the lubricating } \\
\text { oil, diluting the oil and changing its viscosity; (4) carbon to form on } \\
\text { turbocharger and exhaust gas recirculation (EGR) components, } \\
\text { reducing engine efficiency; and/or (5) carbon to clog and damage } \\
\text { the diesel particulate filter (DPF). }\end{array}$ & $\begin{array}{l}\text { MaxxForce Engine } \\
\text { Operation and } \\
\text { Maintenance Manual DT } 9 \\
\text { and } 10 \text { Diesel Engines }\end{array}$ \\
\hline PACCAR & $\begin{array}{l}\text { Idle the engine 3-5 minutes before operating with a load. } \\
\text { CAUTION: Do not allow your engine to idle, at low engine speeds } \\
\text { ( } 400-600 \text { rpm), longer than } 5 \text { minutes. Long periods of idling after } \\
\text { the engine has reached operating temperatures can decrease engine } \\
\text { temperature and cause gummed piston rings, clogged injectors, and } \\
\text { possible engine damage from lack of lubrication. The normal } \\
\text { torsional vibrations generated by the engine can also cause } \\
\text { transmission wear. If an engine } \\
\text { must idle for an extended period of time, it should be done at fast } \\
\text { idle (1,000 rpm or greater). } \\
\text { Caution: Do not operate the engine at low idle for long periods with } \\
\text { engine coolant temperature below the minimum specification in } \\
\text { "Cooling System.” This can result in the following: fuel dilution of } \\
\text { the lubricating oil, carbon build up in the cylinder, cylinder head } \\
\text { valve sticking, and reduced performance. If an engine must idle for } \\
\text { an extended period of time, it should be done at fast idle (1,000 rpm } \\
\text { or greater) until the coolant temperature meets the specification. } \\
\text { Prolonged periods of idling after the engine has reached operating } \\
\text { temperatures can decrease engine temperature and could cause }\end{array}$ & $\begin{array}{l}\text { PACCAR PX-6, PX-7, } \\
\text { PX-8, PX-9 Operator’s } \\
\text { Manuals }\end{array}$ \\
\hline
\end{tabular}




\begin{tabular}{|c|c|c|}
\hline $\begin{array}{l}\text { PAACAR } \\
\text { cont. }\end{array}$ & $\begin{array}{l}\text { engine damage from inadequate lubrication. The normal torsional } \\
\text { vibrations generated can also cause transmission wear. An idle } \\
\text { shutdown feature, available on PACCAR engines, can be } \\
\text { programmed to shut the engine down after a period of low idle } \\
\text { operation with no driver activity. A flashing warning lamp will } \\
\text { inform the driver of an impending shutdown. Failure to comply may } \\
\text { result in equipment or property damage. } \\
\text { Never leave the engine idling when the vehicle is unattended. If the } \\
\text { engine should overheat, immediate action is required to correct the } \\
\text { condition. Failure to take immediate action may result in serious } \\
\text { engine damage. If you must leave your vehicle unattended, shut } \\
\text { down the engine. } \\
\text { Do not idle the engine for excessively long periods. Long periods of } \\
\text { idling, more than } 10 \text { minutes, can cause poor engine performance } \\
\text { Allow the engine to idle } 3 \text { to } 5 \text { minutes before shutting it off after } \\
\text { full-load operation. This allows adequate cooldown of pistons, } \\
\text { cylinders, bearings, and turbocharger components, greatly } \\
\text { increasing service life. }\end{array}$ & \\
\hline $\begin{array}{l}\text { UD Trucks } \\
\text { Corp. } \\
\text { (Volvo/Nissan } \\
\text { Diesel) }\end{array}$ & $\begin{array}{l}\text { There are different recommendations depending on the model year } \\
\text { of the vehicle. } \\
\text { For } 2011 \text { and newer vehicles, there is a warmup switch on the dash } \\
\text { that is used during starting to properly warm up the vehicle. Proper } \\
\text { warmup time depends on ambient air temperature and engine } \\
\text { coolant temperature. Thus the time for proper warmup will vary. } \\
\text { Vehicle application and local laws will dictate idling duration. } \\
\text { Typically, if the vehicle is stationary and not being used, the engine } \\
\text { should be turned off to conserve fuel. Certain vehicles are approved } \\
\text { for “clean idle” if extended idle is required for vehicle application. } \\
\text { The vehicle can also be programmed to shut the engine off } \\
\text { automatically after a predetermined time. }\end{array}$ & $\begin{array}{l}\text { Correspondence with UD } \\
\text { representative }\end{array}$ \\
\hline
\end{tabular}




\section{HEAVY-DUTY VEHICLES}

Summary of idling recommendations for HD vehicles

- Idling beyond 5-15 minutes is excessive and should be avoided.

- Extended idling wastes fuel and causes reduction in fuel economy.

- Excessive idling can create engine wear and carbon soot buildup in the engine and components.

- Idling produces sulfuric acid which can eat into engine surfaces and components.

- Idle time at cooldown is only required if vehicle operated under extended, high power conditions.

\begin{tabular}{|c|c|c|}
\hline OEM & Recommendation & Reference \\
\hline Caterpillar & $\begin{array}{l}\text { Cat engines with ACERT technology do not require long } \\
\text { cooldown periods. Therefore, do not idle for long periods of } \\
\text { time. } \\
\text { —If the vehicle is to be parked for more than } 5 \text { minutes, } \\
\text { shut it down } \\
\text {-If idling for heating or cooling, idle between } 800 \text { and } \\
1,000 \text { rpm } \\
\text { A reduction in idle time from } 50 \% \text { to } 25 \% \text { can improve fuel } \\
\text { economy up to } 4 \% \text {. } \\
\text { Excessive idling wastes fuel, adds contaminants to the oil, } \\
\text { and adds carbons to the combustion chamber. Allow the } \\
\text { engine to warm up during the normal walk-around } \\
\text { inspection. The engine will approach operating temperature } \\
\text { while driving at low revolutions per minute and low power } \\
\text { as you begin your trip. }\end{array}$ & $\underline{\text { http://www.cat.com/cda/files/2222 }}$ \\
\hline Cummins & $\begin{array}{l}\text { Internal combustion engines must not operate at low idle } \\
\text { speed for extended periods of time. This operating condition } \\
\text { may lead to poor engine performance. The idle shutdown } \\
\text { feature, available on most Cummins engines, can be } \\
\text { programmed to shut the engine down after a period of low } \\
\text { idle speed operation with no driver activity. A flashing } \\
\text { warning lamp will inform the driver of an impending } \\
\text { shutdown. If an engine must idle for an extended period of } \\
\text { time, it should be done at fast idle (1,000 rpm or greater). } \\
\text { The Power Take Off (PTO) feature, available on most } \\
\text { Cummins engines, can be programmed to adjust engine } \\
\text { speed with the use of OEM switches to preprogrammed set } \\
\text { points. }\end{array}$ & $\begin{array}{l}\text { Cummins Operation and } \\
\text { Maintenance Manuals ISX, } \\
\text { ISM, Sections 101-015, } \\
\text { "Operating the Engine” }\end{array}$ \\
\hline \multirow[t]{2}{*}{ International } & $\begin{array}{l}\text { Behaviors such as avoiding sudden accelerations and } \\
\text { excessive idling can have a positive impact on each } \\
\text { vehicle's fuel economy. For example, because idling yields } \\
0.0 \text { MPG, every hour of idling reduces fuel economy by } 1 \% \text {. }\end{array}$ & $\begin{array}{l}\text { IC Bus, LLC, School \& } \\
\text { Commercial Bus Fuel Economy, } \\
2008\end{array}$ \\
\hline & $\begin{array}{l}\text { Uses MaxxForce engines (see Navistar). } \\
\text { Uses Cummins engine ISX15 (see Cummins). }\end{array}$ & \\
\hline \multirow[t]{2}{*}{ Kenworth } & $\begin{array}{l}\text { Minimize idling. Five minutes of warmup is generally } \\
\text { adequate, and cooldown is accomplished when pulling in for } \\
\text { parking. To verify the negative effect of excessive idling, } \\
\text { watch the fuel economy display. }\end{array}$ & $\begin{array}{l}\text { Kenworth Truck Company, White } \\
\text { Paper on Fuel Economy, } 2006\end{array}$ \\
\hline & Uses PACCAR engines (see PACCAR). & \\
\hline
\end{tabular}




\begin{tabular}{|c|c|c|}
\hline $\begin{array}{l}\text { Navistar } \\
\text { (Parent } \\
\text { company of } \\
\text { International } \\
\text { trucks, } \\
\text { MaxxForce } \\
\text { engines) }\end{array}$ & $\begin{array}{l}\text { MaxxForce Engines. } \\
\text { Low idle speed for the MaxxForce DT, 9, and } 10 \text { diesel } \\
\text { engines is } 700 \text { rpm (nonadjustable). If the engine coolant } \\
\text { temperature is below } 70^{\circ} \mathrm{C}\left(158^{\circ} \mathrm{F}\right) \text {, the electronic control } \\
\text { module (ECM) will adjust the low idle speed from } 700 \mathrm{rpm} \\
\text { to a maximum of } 875 \mathrm{rpm} \text {. High idle speed is a } \\
\text { nonadjustable factory setting. The high idle setting depends } \\
\text { on the application of the vehicle and has the following } \\
\text { ranges: MaxxForce DT: } 2,600 \text { rpm through } 2,770 \mathrm{rpm} \text {; } \\
\text { MaxxForce } 9 \text { and } 10: 2,325 \mathrm{rpm} \text { through } 2,425 \mathrm{rpm} \text {. To } \\
\text { prevent engine damage, do not extend low idle periods. } \\
\text { Idling periods over } 15 \text { minutes should be avoided. Diesel } \\
\text { engine efficiency is improved when the cylinder temperature } \\
\text { remains high. Low temperature in cylinders may cause the } \\
\text { following: (1) unburned fuel to seep from exhaust manifold } \\
\text { gaskets and vehicle exhaust system connections (seepage } \\
\text { has the dark-colored appearance of lubricating oil); (2) } \\
\text { incomplete combustion, causing unburned fuel to wash } \\
\text { lubricating oil from cylinder sleeves; (3) unburned fuel to be } \\
\text { carried into the lubricating oil, diluting the oil and changing } \\
\text { its viscosity; (4) carbon to form on turbocharger and exhaust } \\
\text { gas recirculation (EGR) components, reducing engine } \\
\text { efficiency; and/or (5) carbon to clog and damage the diesel } \\
\text { particulate filter (DPF). }\end{array}$ & $\begin{array}{l}\text { MaxxForce Engine Operation and } \\
\text { Maintenance Manual } 10 \text { Diesel } \\
\text { Engine, pages 55-58. }\end{array}$ \\
\hline & $\begin{array}{l}\text { Fast idle advance. } \\
\text { The ECM monitors the engine coolant temperature (ECT) } \\
\text { sensor. If the ECT is below } 50^{\circ} \mathrm{F}\left(10^{\circ} \mathrm{C}\right) \text {, the ECM activates } \\
\text { the fast idle advance. Fast idle advance increases engine idle } \\
\text { speed for faster warmup to operating temperature. This } \\
\text { occurs by the ECM monitoring ECT and adjusting fuel } \\
\text { injector operation accordingly. Low idle speed is resumed } \\
\text { when ECT reaches temperatures above } 50^{\circ} \mathrm{F}\left(10^{\circ} \mathrm{C}\right) \text { or the } \\
\text { 100-second period times out. } \\
\text { Low idle speed for Navistar's } 13 \mathrm{~L} \text { diesel engine is } 600 \mathrm{rpm} \text {. } \\
\text { If ECT is below } 158^{\circ} \mathrm{F}\left(70^{\circ} \mathrm{C}\right) \text { and cold ambient protection } \\
\text { (CAP) is enabled, the ECM adjusts the low idle speed from } \\
600 \text { rpm to a maximum of } 1,000 \text { rpm. High idle speed is a } \\
\text { nonadjustable factory setting. } \\
\text { CAUTION: To prevent engine damage, do not extend low } \\
\text { idle periods. Idling periods over } 15 \text { minutes should be } \\
\text { avoided. Diesel engine efficiency is improved when the } \\
\text { cylinder temperature remains high. Low temperature in } \\
\text { cylinders may cause the following. } \\
\text { - Unburned fuel seeping from exhaust manifold gaskets } \\
\text { and vehicle exhaust system connections. This seepage has } \\
\text { the dark-colored appearance of lubricating oil. } \\
\text { - Incomplete combustion, causing unburned fuel to wash } \\
\text { lubricating oil from cylinder sleeves. } \\
\text { - Unburned fuel being carried into the lubricating oil, } \\
\text { diluting the oil and changing its viscosity. } \\
\text { - Carbon forming on internal components of turbocharger } \\
\text { and EGR, reducing engine efficiency. } \\
\text { - Carbon clogging and damaging the DPF. }\end{array}$ & $\begin{array}{l}\text { MaxxForce Engine Operation and } \\
\text { Maintenance Manual 13L Diesel } \\
\text { Engines }\end{array}$ \\
\hline
\end{tabular}




\begin{tabular}{|c|c|c|}
\hline Navistar cont. & $\begin{array}{l}\text { All vehicles that are in compliance with the clean idle } \\
\text { calibrations will have a "Certified Clean Idle" label applied } \\
\text { to the hood or door of the vehicle. } \\
\text { Before shutting down an engine that has reached operating } \\
\text { temperature, idle the engine for } 2 \text { to } 3 \text { minutes, allowing the } \\
\text { hottest engine components to dissipate some of their internal } \\
\text { heat. Idling is recommended if an engine has been running } \\
\text { at maximum horsepower. }\end{array}$ & \\
\hline \multirow[t]{2}{*}{ PACCAR } & 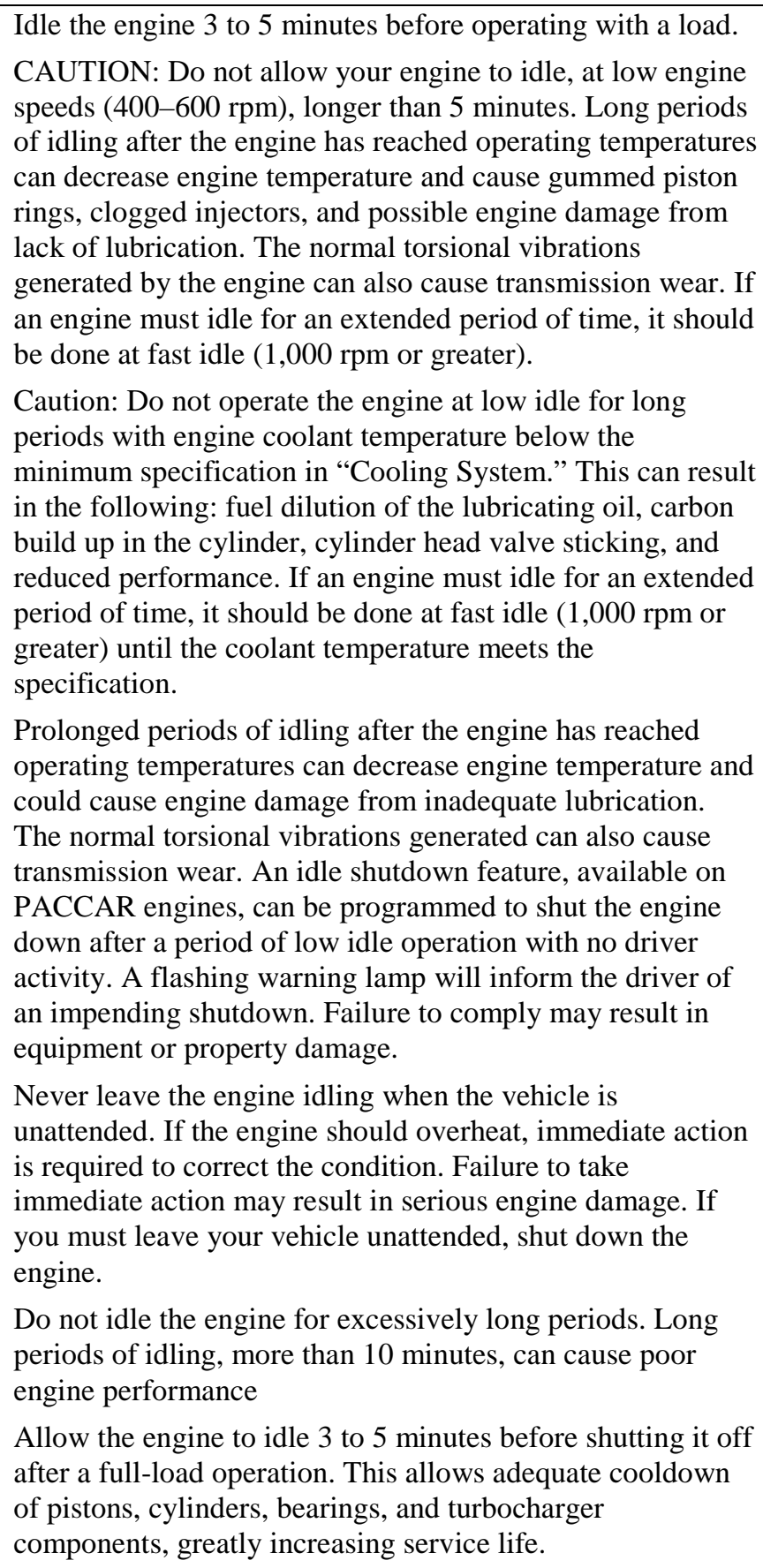 & PACCAR PX-9 Operators Manual \\
\hline & $\begin{array}{l}\text { Idle the engine } 3 \text { to } 5 \text { minutes before operating with a load. } \\
\text { CAUTION: Do not allow your engine to idle, at low }\end{array}$ & \\
\hline
\end{tabular}




\begin{tabular}{|c|c|c|}
\hline $\begin{array}{l}\text { PACCAR } \\
\text { Cont. }\end{array}$ & $\begin{array}{l}\text { revolutions per minute ( } 400-600 \text { rpm), longer than } 5 \text { minutes. } \\
\text { Long periods of idling after the engine has reached operating } \\
\text { temperatures can decrease engine temperature and cause } \\
\text { gummed piston rings, clogged injectors, and possible engine } \\
\text { damage from lack of lubrication. The normal torsional } \\
\text { vibrations generated by the engine can also cause } \\
\text { transmission wear. If an engine must idle for an extended } \\
\text { period of time, it should be done at fast idle (1,000 rpm or } \\
\text { greater). } \\
\text { Caution: Do not operate the engine at low idle for long } \\
\text { periods with engine coolant temperature below the } \\
\text { minimum specification in “Cooling System.” This can result } \\
\text { in the following: fuel dilution of the lubricating oil, carbon } \\
\text { build up in the cylinder, cylinder head valve sticking, and } \\
\text { reduced performance. If an engine must idle for an extended } \\
\text { period of time, it should be done at fast idle (1,000 rpm or } \\
\text { greater) until the coolant temperature meets the } \\
\text { specification. }\end{array}$ & \\
\hline $\begin{array}{l}\text { PACCAR } \\
\text { Cont. }\end{array}$ & $\begin{array}{l}\text { Prolonged periods of idling after the engine has reached } \\
\text { operating temperatures can decrease engine temperature and } \\
\text { could cause engine damage from inadequate lubrication. } \\
\text { The normal torsional vibrations generated can also cause } \\
\text { transmission wear. An idle shutdown feature, available on } \\
\text { PACCAR engines, can be programmed to shut the engine } \\
\text { down after a period of low idle operation with no driver } \\
\text { activity. A flashing warning lamp will inform the driver of } \\
\text { an impending shutdown. Failure to comply may result in } \\
\text { equipment or property damage. } \\
\text { Idle the engine at } 1,000 \text { rpm for } 4 \text { minutes. Then low idle for } \\
30 \text { seconds before shutdown. This will allow circulating } \\
\text { coolant and lubricating oil to carry heat away from the } \\
\text { cylinder head, valves, pistons, cylinder liners, turbocharger, } \\
\text { and bearings, preventing engine damage that could result } \\
\text { from uneven cooling. }\end{array}$ & $\begin{array}{l}\text { PACCAR MX-13 Operator's } \\
\text { Manual }\end{array}$ \\
\hline Peterbilt & Uses PACCAR engines (see PACCAR). & \\
\hline Volvo & $\begin{array}{l}\text { Idling: Diesel engines are electronically governed. The idle } \\
\text { speed is preprogrammed from the manufacturer. Low idle } \\
\text { speed is adjustable within certain limits (for most engines } \\
\text { between } 600 \text { and } 750 \text { rpm). } \\
\text { The common belief that idling a diesel engine causes no } \\
\text { engine damage is wrong. Idling produces sulfuric acid, } \\
\text { which breaks down the oil and eats into bearings, rings, } \\
\text { valve stems, and engine surfaces. } \\
\text { Note: Avoid excessive idling. If the vehicle is parked for } \\
\text { more than } 5 \text { minutes, stop the engine. An engine can burn } \\
\text { from } 3 \text { to } 5.5 \text { liters ( } 0.75 \text { to } 1.5 \text { gallons) of fuel per hour } \\
\text { while idling. During long engine idling periods, the engine } \\
\text { coolant temperature may fall below the normal operating } \\
\text { range. Incomplete combustion of fuel during the warmup } \\
\text { period can cause dilution of the oil in the crankcase; } \\
\text { formation of lacquer or gummy deposits on the valves, } \\
\text { pistons, and rings; and rapid accumulation of sludge in the } \\
\text { engine. }\end{array}$ & US 2012 Operator’s Manual \\
\hline
\end{tabular}




\begin{tabular}{|c|c|c|}
\hline $\begin{array}{l}\text { Anonymous } \\
\text { North } \\
\text { American } \\
\text { Truck } \\
\text { Manufacturer }\end{array}$ & $\begin{array}{l}\text { "I would prefer no engine idle, but our customers demand } \\
\text { that their trucks idle for basic reasons of heating or cooling } \\
\text { of the cab by sleeper units for driver comfort. Average } \\
\text { sleeper unit has a } 40 \% / 50 \% \text { average } 40 \% \text { idle times and } \\
50 \% \text { on highway use (sleep time /work time). } \\
\text { At basic start up, the engine is ready to start work. Diesel } \\
\text { engines work off the heat of compressed air in the cylinders. } \\
\text { At the first power stroke you have the heat needed to } \\
\text { completely burn the fuel. } \\
\text { Idle times have always been an issue and a waste of fuel. It } \\
\text { was believed that the older engines needed to idle to warm } \\
\text { up before use. The only difference that comes with age is } \\
\text { that older diesel engines have a lower compression. Based } \\
\text { on the age most engine compression has always been higher } \\
\text { than } 750 \text { psi of compression, but you only need 370 psi for } \\
\text { completed fuel burn (via car diesel). Today's truck engines } \\
\text { are way past } 370 \text { psi, and pressures are as high today as } \\
3,000 \text { psi of compressed air per cylinder. So with the first } \\
\text { power stoke you have the heat needed for complete } \\
\text { combustion of fuel delivered to the cylinder. } \\
\text { Effects of idling: It's a waste of fuel and increases wear of } \\
\text { our engines because of idle speeds (650-700 rpm). The } \\
\text { engine works less effectively when compression is lower } \\
\text { because compressed air passes the compression rings of the } \\
\text { piston. Compressed air passes the rings and transfers } \\
\text { unburned oils and fuels to the engine crankcase and causes } \\
\text { greater increase of wear to engine components. At higher } \\
\text { engine speeds the engine makes a complete burning of the } \\
\text { fuels at the higher compressed air and seals compression } \\
\text { rings for better complete burn of fuels with less transfer to } \\
\text { crankcase.” }\end{array}$ & $\begin{array}{l}\text { Correspondence with } \\
\text { manufacturer's representative }\end{array}$ \\
\hline
\end{tabular}




\section{CONTACT INFORMATION}

Questions or comments should be directed to:

Scott Curran, curransj@ornl.gov

Melissa Lapsa, lapsamv@ornl.gov

\section{ACKNOWLEDGEMENTS}

This work was supported by Oak Ridge National Laboratory’s Sustainable Campus Initiative.

https://sustainability-ornl.org

The authors wish to thank Brian West and VJ Ewing at ORNL and Jonathan Overly with ET Clean Fuels for reviewing this document and providing valuable input. 